\title{
COVID-19: Before the Fall, An Evidence-Based Narrative Review of Treatment Options
}

Nicholas Rebold · Dana Holger · Sara Alosaimy · Taylor Morrisette •

Michael Rybak

Received: November 9, 2020 / Accepted: January 8, 2021 / Published online: January 25, 2021

(c) The Author(s) 2021

\section{ABSTRACT}

The 2019 novel coronavirus (COVID-19) has quickly become one of the most dire international pandemic crises since the 1918 Spanish flu. Evidence for COVID-19 pharmacological therapies has shown rapid growth and a diverse array of results, but an assessment of the value of each piece of evidence must be reinforced. This article aims to review utilized therapies, the evidence level supporting these therapies, as well as drugs under investigation for the treatment of COVID-19. Primary scrutinized therapies include antiviral regimens, such as remdesivir, hydroxychloroquine/chloroquine, lopinavir/ritonavir, immunomodulating drugs, such as corticosteroids and interleukin (IL)

Supplementary Information The online version contains supplementary material available at https:// doi.org/10.1007/s40121-021-00399-6.

N. Rebold · D. Holger · S. Alosaimy · T. Morrisette ·

M. Rybak ( $\square)$

Anti-Infective Research Laboratory, Eugene

Applebaum College of Pharmacy and Health

Sciences, Wayne State University, Detroit, MI, USA

e-mail: m.rybak@wayne.edu

M. Rybak

Department of Pharmacy, Detroit Receiving

Hospital, Detroit, MI, USA

M. Rybak

Division of Infectious Diseases, School of Medicine,

Wayne State University, Detroit, MI, USA inhibitors, and other therapies including convalescent plasma. Only one therapy, dexamethasone, has shown a mortality benefit in randomized controlled trials and summarized evidence for other therapies show limited positive results. Reviewing these therapies in a historical way shows how limited evidence can drive therapy decisions. A broad summary of available evidence can assist clinicians in a return to hierarchical assessments of evidence which can lead to safer patient outcomes, improved distribution of resources, and better targets for appropriate therapy decisions.

Keywords: Coronavirus; COVID; COVID-19; Evidence; Narrative review; Pharmacologic; Review; Therapy; Treatment 


\section{Key Summary Points}

Evidence for COVID-19 pharmacological therapies has shown rapid growth and a diverse array of results, but an assessment of the value of each piece of evidence must be reinforced

This article aims to review utilized therapies, the evidence level supporting these therapies, as well as drugs under investigation for the treatment of COVID19

Only one therapy, dexamethasone, has shown a mortality benefit in randomized controlled trials and summarized evidence for other therapies show limited positive results

A broad summary of available evidence can assist clinicians in a return to hierarchical assessments of evidence

\section{DIGITAL FEATURES}

This article is published with digital features, including a summary slide, to facilitate understanding of the article. To view digital features for this article go to https://doi.org/10.6084/ m9.figshare.13536953.

\section{INTRODUCTION}

The newly discovered betacoronavirus, severe acute respiratory syndrome coronavirus 2 (SARS-CoV-2), has quickly become one of the most dire international pandemic crises since the 1918 Spanish flu, which resulted in 20 million deaths, including 500,000 in the USA [1]. First discovered in Wuhan, China in December 2019, SARS-CoV-2 has now spread to nearly every country across the globe, with the USA leading the charge in the number of confirmed cases by country. As of December 1, 2020, the number of confirmed cases has climbed to over

$60,000,000$ with almost 1.5 million deaths worldwide [2]. The virus manifests as an acute viral respiratory infection referred to as coronavirus disease 2019 (COVID-19) primarily characterized by cough, fever, shortness of breath, muscle pain, loss of taste or smell, and/or no symptoms at all [3]. Management of COVID-19 is similar to many viral respiratory illnesses in that therapy is largely supportive, but respiratory failure from acute respiratory distress syndrome (ARDS) is the leading cause of mortality. Studies suggest that $20-30 \%$ of hospitalized patients with COVID-19 disease progress to ARDS $[4,5]$. Currently, there are still no US Food and Drug Administration (FDA)-approved therapies for the treatment of SARS-CoV-2 except for an emergency use authorization for remdesivir and scattered data supporting other agents such as dexamethasone. As a result of scant data early in the course of the pandemic, many institutions had implemented treatment algorithms based on observational trials and in vitro activity against SARS-CoV-2 and similar coronaviruses, such as severe acute respiratory syndrome coronavirus 1 (SARS-CoV-1) and Middle East respiratory syndrome (MERS). Many treatment options have been suggested, utilized, and are in trials for their effectiveness against SARSCoV-2, but the level of evidence varies between these therapies.

This article aims to review recently utilized therapies, the evidence supporting these therapies, as well as drugs under investigation for the treatment of COVID-19. This article is based on previously conducted studies and does not contain any new studies with human participants or animals performed by any of the authors. The authors agree with both the Infectious Diseases Society of America (IDSA) and National Institutes of Health (NIH) guidelines on the treatment and management of patients with COVID-19, which encourage more experimental therapies to be performed within the context of a clinical trial [6]. To this end, a comprehensive understanding of current treatment evidence will help providers assess risks and benefits, identify gaps in research, and direct attention towards the most promising drugs being screened to treat COVID-19. 


\section{Hierarchy of Research Designs}

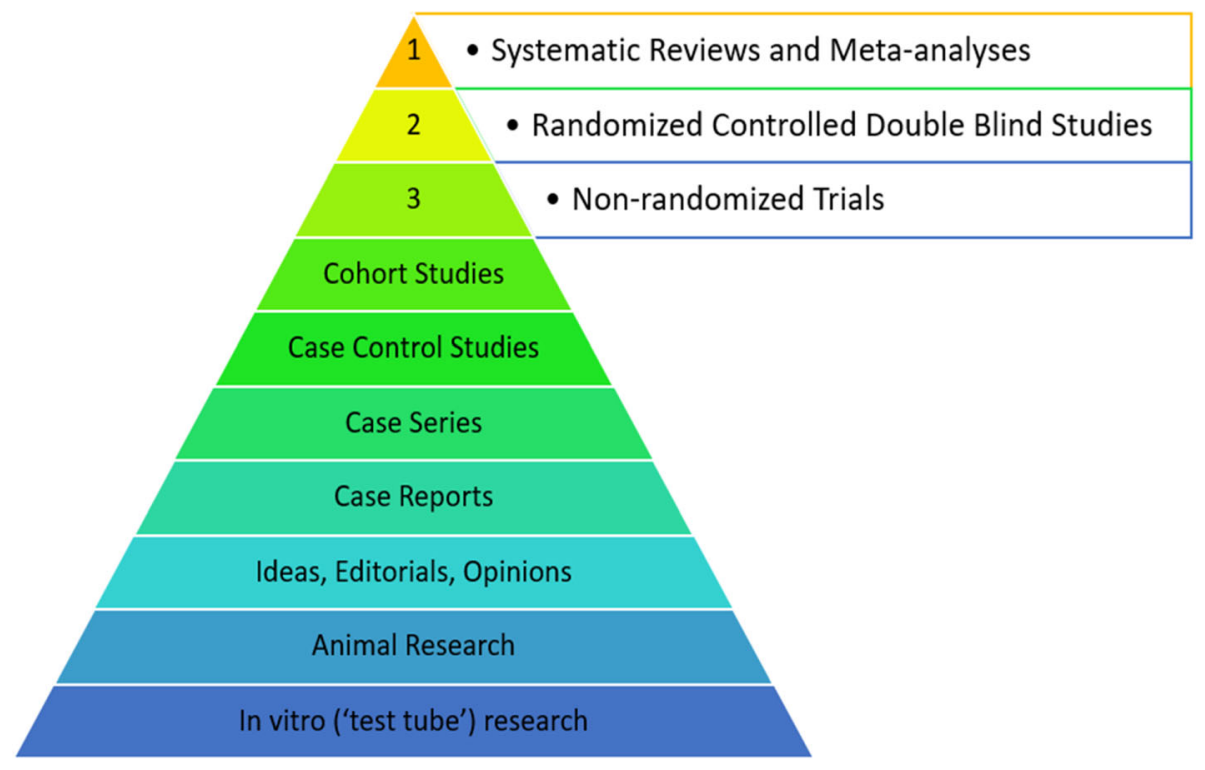

Fig. 1 Chart adapted from Guide to Research Methods: The Evidence Pyramid. SUNY Downstate Medical Center. Medical Research Library of Brooklyn EBM Resources

This article is based on previously conducted studies and does not contain any new studies with human participants or animals performed by any of the authors.

\section{GENERAL PRINCIPLES}

When discussing evidence between pharmacologic therapies, one must remember the hierarchy of evidence (Fig. 1). It is vital to not let desperation replace evidence when recommending potential therapies. Too often, there is harm perpetrated with the best of intentions, before there can be adequate data to assess the therapy. This can be seen in prior pandemics and early harmful "therapies" for human immunodeficiency virus (HIV) and other respiratory viruses $[7,8]$. With COVID-19 entering 11 months since its characterization as a pandemic, more studies and randomized controlled trial (RCT) results are surfacing regarding treatment for COVID-19. As clinicians and researchers, we should refer patients and healthcare professionals to well-performed RCTs to make decisions as to whether these antimalarials and/or antibiotics should be utilized in the treatment of COVID-19. Trials that only provide a low to moderate level of evidence can deprive high-level trials of potential subjects. Also therapies that are not sufficiently evidence-based can bias the populations for RCTs that consider the definition of "standard of care". Understanding how to categorize and assess scientific evidence is important when discussing the strengths and weaknesses of studies that have been used for the IDSA and NIH recommendations, and it is important to prioritize high-level evidence in these discussions. An updated review of the evidence behind COVID-19 therapies can help more providers understand the breadth and depth of historical COVID-19 treatment evidence and assess gaps and potential research for the future pharmacologic treatments.

The driving forces behind many of the early therapies for COVID-19 were prior studies among SARS and MERS viruses. The initial 
Table 1 Key parameters used for comparing in vitro data

\begin{tabular}{|c|c|}
\hline Term & Definition \\
\hline $\mathrm{EC}_{50}$ & $\begin{array}{l}\text { Effective concentration needed to achieve } 50 \% \text { of } \\
\text { maximal response ( } 50 \% \text { viral inhibition) }\end{array}$ \\
\hline $\mathrm{IC}_{50}$ & $\begin{array}{l}\text { Inhibitory concentration needed to inhibit a } \\
\text { process by } 50 \% \text { (usually intended for antagonist } \\
\text { drug potency, but often interchanged with } \mathrm{EC}_{50} \\
\text { when discussing antiviral therapy) }\end{array}$ \\
\hline $\mathrm{CC}_{50}$ & $\begin{array}{l}\text { Cytotoxic concentration needed to cause death } \\
\text { among } 50 \% \text { of host cells }\end{array}$ \\
\hline SI & $\begin{array}{l}\mathrm{CC}_{50} / \mathrm{EC}_{50} \text {; selectivity index to describe a given } \\
\text { drug's therapeutic window }\end{array}$ \\
\hline
\end{tabular}

studies with SARS and MERS revealed certain agents that could effectively inhibit coronaviruses at achievable concentrations in cell or animal models [9-11]. When comparing efficacy for various therapies with little RCT data behind them, often the discussion begins around comparing in vitro data. The main principles of comparing in vitro data involve quantifying an agent's half-maximal effective concentration $\left(\mathrm{EC}_{50}\right)$, half-maximal inhibitory concentration $\left(\mathrm{IC}_{50}\right)\left(\mathrm{EC}_{50}\right.$ and $\mathrm{IC}_{50}$ are sometimes interchanged when the substance is intended to inhibit viral replication), and 50\% cytotoxic concentration $\left(\mathrm{CC}_{50}\right)$ (Table 1) [12].

One can assess higher levels of evidence by building on these definitions for comparing in vitro research. Much of the same definitions are used in animal research, where $\mathrm{EC}_{50}$ can apply to the clinical syndrome in an animal and $\mathrm{CC}_{50}$ can apply to a population of animals. However, there are assumptions in targeting $\mathrm{EC}_{50}$ values which have not been borne out by scientific evidence. It is unclear whether $\mathrm{EC}_{50}$ values are important targets, and in one of the only true pharmacodynamic studies there was a lack of antiviral effect of a drug despite having serum and lung concentrations above the $\mathrm{EC}_{50}$ value. One must keep the primary target of the human host in mind and ensure outcomes are evaluated rather than abstract $\mathrm{EC}_{50}$ values which may not predict outcomes [13]. The level of evidence rises when the data is derived from human hosts, with larger sample sizes, and more controlled randomized trials associated with eliminating confounders and bias.

Taking the recommendation rating scheme and adapting it from the NIH guidelines, one can apply a simple way to assess many different types of clinical evidence (Table 2). A systematic search was undertaken from March 2020 to September 2020 utilizing PubMed search terms of "covid", "covid-19", and "covid treatment" including pharmacologic studies only. This narrative review will focus on the quality of evidence and the positive or negative effects of each therapy in evidence. The strength of the recommendations will remain with the NIH and IDSA given their consensus guidelines among a panel of experts. Each study will be evaluated on a quality of evidence scale from I for an RCT as the highest level of evidence to VI for in vitro research or P for pending investigation (Table 3). The studies will also be evaluated on a strength of effect scale across a range from $(---)$ for strong $(\geq 5 \%)$ negative effect on mortality to $(+++)$ for strong $(\geq 5 \%)$ positive effect on mortality (Table 3 ).

\section{TREATMENT OPTIONS}

\section{Antiviral Therapies}

\section{Remdesivir}

Remdesivir is an adenosine nucleotide analogue that interferes with the action of viral RNA polymerases that ultimately decreases viral RNA production. It was originally developed to treat Ebola virus and has been found to have inhibitory effects on other viruses. With demonstrated in vitro activity against SARS-CoV-2 and in vivo activity against similar coronaviruses, remdesivir became an early contender among the potential treatment options against SARSCoV-2 (Table 4) [24, 79]. As a result of high demand, the manufacturer (Gilead Sciences, Inc.) transitioned from individual compassionate use requests to an expanded access program in concert with the FDA [80]. New individual compassionate use requests were accepted specifically for pregnant women and children 
Table 2 Recommendation rating scheme for NIH COVID-19 assessment of evidence. Chart adapted from NIH Table 1 in ref. [14]

\begin{tabular}{|c|c|c|c|}
\hline \multicolumn{2}{|c|}{$\begin{array}{l}\text { Strength of } \\
\text { recommendation }\end{array}$} & \multicolumn{2}{|c|}{$\begin{array}{l}\text { Quality of evidence for } \\
\text { recommendation }\end{array}$} \\
\hline A & $\begin{array}{l}\text { Strong } \\
\text { recommendation } \\
\text { for the statement }\end{array}$ & I & $\begin{array}{l}\text { One or more randomized } \\
\text { trials with clinical } \\
\text { outcomes and/or } \\
\text { validated laboratory } \\
\text { endpoints }\end{array}$ \\
\hline B & $\begin{array}{l}\text { Moderate } \\
\text { recommendation } \\
\text { for the statement }\end{array}$ & II & $\begin{array}{l}\text { One or more well- } \\
\text { designed, non- } \\
\text { randomized trials or } \\
\text { observational cohort } \\
\text { studies }\end{array}$ \\
\hline $\mathrm{C}$ & $\begin{array}{l}\text { Optional } \\
\text { recommendation } \\
\text { for the statement }\end{array}$ & III & Expert opinion \\
\hline
\end{tabular}

under 18 years of age [81]. On April 29, 2020, the FDA granted emergency use authorization (EUA) for the investigational intravenous antiviral drug to treat severe COVID-19 (defined as oxygen saturation $\leq 94 \%$ ). An EUA is intended to provide the availability of a drug during an emergency. It is a temporary approval and does not take the place of the formal new drug application submission, review, and approval process.

Multiple clinical trials remain underway to assess remdesivir's role in the treatment of COVID-19 [16, 18-23]. It was also the first COVID-19 therapy used in the first documented patient case in the USA [22]. Initially, the data for compassionate use of remdesivir was released for patients hospitalized with severe COVID-19 to support its use. The design was an observational study of patients who were provided compassionate use remdesivir, with no control group. There were 53 patients who received at least one dose (200 $\mathrm{mg}$ or $100 \mathrm{mg} \mathrm{IV}$ ) of remdesivir with analyzable data at different clinical sites, 30/53 (57\%) were mechanically ventilated and $4 / 53 \quad(8 \%)$ were on extracorporeal membrane oxygenation (ECMO). At a median of 18-day follow-up, $36 / 53(68 \%)$ had an improvement in oxygensupport class, $25 / 53$ (47\%) of patients were discharged, and 7/53 (13\%) patients died. While $68 \%$ of patients improved on therapy defined as oxygen-support class, it is difficult to assess the significance of results with the lack of a control group [21].

However, the EUA that came after the order for compassionate use was based on a stronger set of data from the Adaptive COVID-19 Treatment Trial (ACTT) group in an RCT. In one of the strongest volumes of evidence to date, the National Institute of Allergy and Infectious Diseases (NIAID) ACTT-1 Study was a randomized, double-blind, placebo-controlled clinical trial evaluating remdesivir (200 mg daily $\times 1$ day followed by $100 \mathrm{mg}$ daily $\times 9$ days, up to 10 days total) in hospitalized adult patients with COVID-19. The trial enrolled 1063 hospitalized patients who received remdesivir or placebo allocated in a 1:1 ratio. In a preliminary analysis of the primary endpoint after 606 recoveries were attained, the median time to recovery was 11 days in the remdesivir group compared to 15 days in the placebo group (HR 1.31; 95\% confidence interval $[\mathrm{CI}] 1.12-1.54, p<0.001)$. All-cause mortality was $8.0 \%$ for the remdesivir group versus $11.6 \%$ for the placebo group $(p=0.059)$ [16]. This study provided initial strong evidence for a modest benefit of remdesivir. Subsequently to this, Gilead Sciences, Inc. has given drug to the federal government to distribute to in-need hospitals while ramping up production for more cases. Another of Gilead's clinical trials compared 5 days versus 10 days of therapy for remdesivir. The randomized, open-label, multicenter study (GS-US-540-5773) suggested that patients receiving a 10-day treatment course had similar improvement in clinical status compared with those receiving a 5-day treatment course (10-day vs. 5-day odds ratio 0.76; $95 \%$ CI $0.51-1.13$ on day 14 ). This gives rise to the suggestion of a 5-day duration, with possible extension to 10 days if no clinical improvement is demonstrated in an intensive care unit (ICU) setting [82]. The NIH guidelines have provided specific recommendations for 5 days 
Table 3 Evidence assessment scheme for assessment of evidence for review

\begin{tabular}{|c|c|c|c|}
\hline \multicolumn{2}{|c|}{ Quality of evidence } & \multicolumn{2}{|c|}{$\begin{array}{l}\text { Effect size strength (only } \\
\text { evidence I-II) }\end{array}$} \\
\hline I & $\begin{array}{l}\text { Randomized trial with } \\
\text { clinical outcomes } \\
\text { and/or validated } \\
\text { laboratory endpoints }\end{array}$ & +++ & $\begin{array}{l}\text { Strong positive } \\
\text { effect on } \\
\text { mortality } \\
(\geq 5 \%)\end{array}$ \\
\hline II & $\begin{array}{l}\text { Non-randomized trial } \\
\text { or observational } \\
\text { cohort study }\end{array}$ & ++ & $\begin{array}{l}\text { Positive effect on } \\
\text { mortality } \\
(<5 \%)\end{array}$ \\
\hline III & $\begin{array}{l}\text { Single-arm study or } \\
\text { case series/reports }\end{array}$ & + & $\begin{array}{l}\text { Some positive } \\
\text { effect on an } \\
\text { outcome }\end{array}$ \\
\hline IV & $\begin{array}{l}\text { Editorials/expert } \\
\text { opinion }\end{array}$ & 0 & $\begin{array}{l}\text { No significant } \\
\text { effect noted } \\
\text { from treatment }\end{array}$ \\
\hline $\mathrm{V}$ & $\begin{array}{l}\text { Animal or animal- } \\
\text { model research }\end{array}$ & - & $\begin{array}{l}\text { Some negative } \\
\text { effect/increased } \\
\text { adverse events }\end{array}$ \\
\hline VI & $\begin{array}{l}\text { In vitro research or AI- } \\
\text { based drug selection }\end{array}$ & -- & $\begin{array}{l}\text { Negative effect on } \\
\text { mortality } \\
(<5 \%)\end{array}$ \\
\hline $\mathrm{P}$ & $\begin{array}{l}\text { In-progress clinical } \\
\text { trials }\end{array}$ & --- & $\begin{array}{l}\text { Strong negative } \\
\text { effect on } \\
\text { mortality } \\
(\geq 5 \%)\end{array}$ \\
\hline & & $\mathrm{N} / \mathrm{A}$ & Not applicable \\
\hline
\end{tabular}

of remdesivir when on supplemental oxygen but not mechanical ventilation, while NIH recommended 10 days for those patients on mechanical ventilation or ECMO.

After this set of initial studies and results, remdesivir's portfolio of evidence became further filled with completed trials. The full results for the ACTT-1 trial have been released that finalized a total of 1062 patients' results and provide the strongest piece of evidence for utilizing remdesivir. The primary results showed that the median recovery time for the remdesivir group was 10 days compared to standard of care's 15 days (RR for recovery 1.29 ; 95\% CI $1.12-1.49, \quad p<0.001)$ and showing 29-day mortality of $11.4 \%$ in the remdesivir group and $15.2 \%$ in the placebo group (HR $0.73 ; 95 \% \mathrm{CI}$ $0.52-1.03)$. Adverse events were lower at $24.6 \%$ who received remdesivir and at $31.6 \%$ for placebo [17]. Over 15 RCTs are being conducted to determine the efficacy and safety of remdesivir in the treatment of COVID-19 [83]. In stark contrast to the positive results from ACTT- 1 in the USA, in one of the most recent and broadest clinical trials to date, the World Health Organization (WHO) international SOLIDARITY trial allocated 2750 patients to remdesivir and 4088 to no study drug and found a 28-day mortality relative risk ratio of 0.95 (95\% CI 0.81-1.11, $p=0.50$ ) which showed no statistically significant reduction in mortality. Total 28-day mortality was $12 \%$, and this was measured along Kaplan-Meier curves. SOLIDARITY, when gathering the great amount of patients in combination with the finalized ACTT-1 results, has shown that there is no statistically significant difference in mortality with remdesivir use [15]. While initial results with the ACTT-1 trial seemed promising, final results in combination with the SOLIDARITY trial have shown remdesivir has limited utility in curbing mortality rates and that it may have limited efficacy. This complete picture of evidence has complicated many healthcare centers' aggressive uptake of this drug as one of the few pharmacological options for patients with COVID-19. Guidelines have split on remdesivir's ultimate use, with the NIH and IDSA guidelines advocating for remdesivir's use in severe COVID-19, and WHO issuing a conditional recommendation against remdesivir's use in hospitalized patients given the lack of evidence that it improves survival or has an important effect on need for mechanical ventilation or time to clinical improvement $[14,84]$. The dosing table below provides complete context on how the drug should be used 
Table 4 Evidence review summary of pharmacologic treatment for COVID-19

\begin{tabular}{|c|c|c|c|c|c|}
\hline Drug class & Drug & Evidence/studies & Interventions & $\begin{array}{l}\text { Quality of } \\
\text { evidence } \\
\text { (I-VI) }\end{array}$ & $\begin{array}{l}\text { Effect size strength } \\
\text { (only evidence I-II) }\end{array}$ \\
\hline \multirow[t]{37}{*}{ Antiviral } & Remdesivir & $\begin{array}{l}\text { SOLIDARITY, Pan } \\
\text { et al. [15] }\end{array}$ & $\begin{array}{l}\text { RDV vs. } P B O, H C Q \text { vs. } P B O, L P V / r \text { vs. } P B O, \\
L P V / r+I N F \text { vs. PBO, INF vs. PBO }\end{array}$ & I & 0 \\
\hline & & $\begin{array}{l}\text { ACTT-1, Beigel et al. } \\
{[16,17]}\end{array}$ & RDV vs. $\mathrm{PBO}$ & I & + \\
\hline & & Wang et al. [18] & RDV vs. PBO & I & 0 \\
\hline & & Goldman et al. [19] & RDV 5d vs. RDV $10 \mathrm{~d}$ & I & 0 \\
\hline & & Spinner et al. [20] & RDV 5d vs. RDV $10 \mathrm{~d}$ vs. Std & I & $\begin{array}{l}\mathrm{RDV} 5 \mathrm{~d}+ \\
\operatorname{RDV} 10 \mathrm{~d} 0\end{array}$ \\
\hline & & Grein et al. [21] & $\mathrm{RDV}$ & II & $\mathrm{N} / \mathrm{A}$ \\
\hline & & Holshue et al. [22] & Case report & III & \\
\hline & & Williamson et al. [23] & $\mathrm{RDV}$ in rhesus macaques & $\mathrm{V}$ & \\
\hline & & Wang et al. [24] & RDV, CLQ in vitro & VI & \\
\hline & $\begin{array}{l}\text { Hydroxychloroquine/ } \\
\text { chloroquine }\end{array}$ & $\begin{array}{l}\text { SOLIDARITY, Pan } \\
\text { et al. [15] }\end{array}$ & $\begin{array}{l}\text { RDV vs. PBO, HCQ vs. } P B O, L P V / r \text { vs. } P B O \text {, } \\
\text { LPV/r + INF vs. PBO, INF vs. PBO }\end{array}$ & I & 0 \\
\hline & & Cavalcanti et al. [25] & Std vs. HCQ vs. HCQ + AZI & I & HCQ - \\
\hline & & & & & $\mathrm{HCQ}+\mathrm{AZI}-$ \\
\hline & & $\begin{array}{l}\text { HCQ: RECOVERY } \\
\text { trial, Horby et al. [26] }\end{array}$ & Std vs. HCQ & I & - \\
\hline & & Tang et al. [27] & Std vs. HCQ & I & - \\
\hline & & Chen et al. [28] & Std vs. HCQ & I & + \\
\hline & & Magagnoli et al. [29] & Std vs. HCQ vs. HCQ + AZI & II & $\begin{array}{l}\mathrm{HCQ}-- \\
\mathrm{HCQ}+\mathrm{AZI} 0\end{array}$ \\
\hline & & Mahevas et al. [30] & HCQ vs. PBO & II & 0 \\
\hline & & Rosenberg et al. [31] & Std vs. HCQ vs. AZI vs. HCQ + AZI & II & HCQ 0 \\
\hline & & & & & AZI 0 \\
\hline & & & & & $\mathrm{HCQ}+\mathrm{AZI}-$ \\
\hline & & Arshad et al. [32] & Std vs. HCQ vs. AZI vs. HCQ + AZI & II & $\begin{array}{l}\mathrm{HCQ}++ \\
\text { AZI } 0\end{array}$ \\
\hline & & & & & $\mathrm{HCQ}+\mathrm{AZI}+$ \\
\hline & & Yu et al. [33] & Std vs. HCQ & II & +++ \\
\hline & & Ip et al. [34] & Outpt: Std vs. HCQ & II & + \\
\hline & & Geleris et al. [35] & Std vs. HCQ & II & 0 \\
\hline & & Castelnuovo et al. [36] & Std vs. HCQ & II & ++ \\
\hline & & Gautret et al. $[37,38]$ & Std vs. HCQ \pm AZI & III & \\
\hline & & Molina et al. [39] & HCQ + AZI PCR-time & III & \\
\hline & & Wang et al. [24] & $\mathrm{RDV}, \mathrm{CLQ}$ in vitro & VI & \\
\hline & Favipiravir & Cai et al. [40] & FPV vs. $L P V / r$ & II & + \\
\hline & Galidesivir & BioCryst $[41]$ & Phase I and II & I & $\mathrm{P}$ \\
\hline & Lopinavir/ritonavir & Li et al. [42] & Std vs. LPV/r vs. arbidol & I & - \\
\hline & & $\begin{array}{l}\text { SOLIDARITY, Pan } \\
\text { et al. [15] }\end{array}$ & $\begin{array}{l}\text { RDV vs. PBO, HCQ vs. PBO, LPV/r vs. PBO, } \\
\mathrm{LPV} / \mathrm{r}+\mathrm{INF} \text { vs. PBO, INF vs. PBO }\end{array}$ & I & 0 \\
\hline & & RECOVERY trial [43] & Std vs. $L P V / r$ & I & 0 \\
\hline & & Cao et al. [44] & Std. vs. $L P V / r$ & I & 0 \\
\hline & Sofosbuvir/daclatasvir & Eslami et al. [45] & SOF/DCV vs. RBV & II & +++ \\
\hline & Oseltamivir & Tan et al. [46] & In vitro & VI & \\
\hline Immunomodulators & Colchicine & Deftereos et al. [47] & Std vs. Colc & I & + \\
\hline
\end{tabular}


Table 4 continued

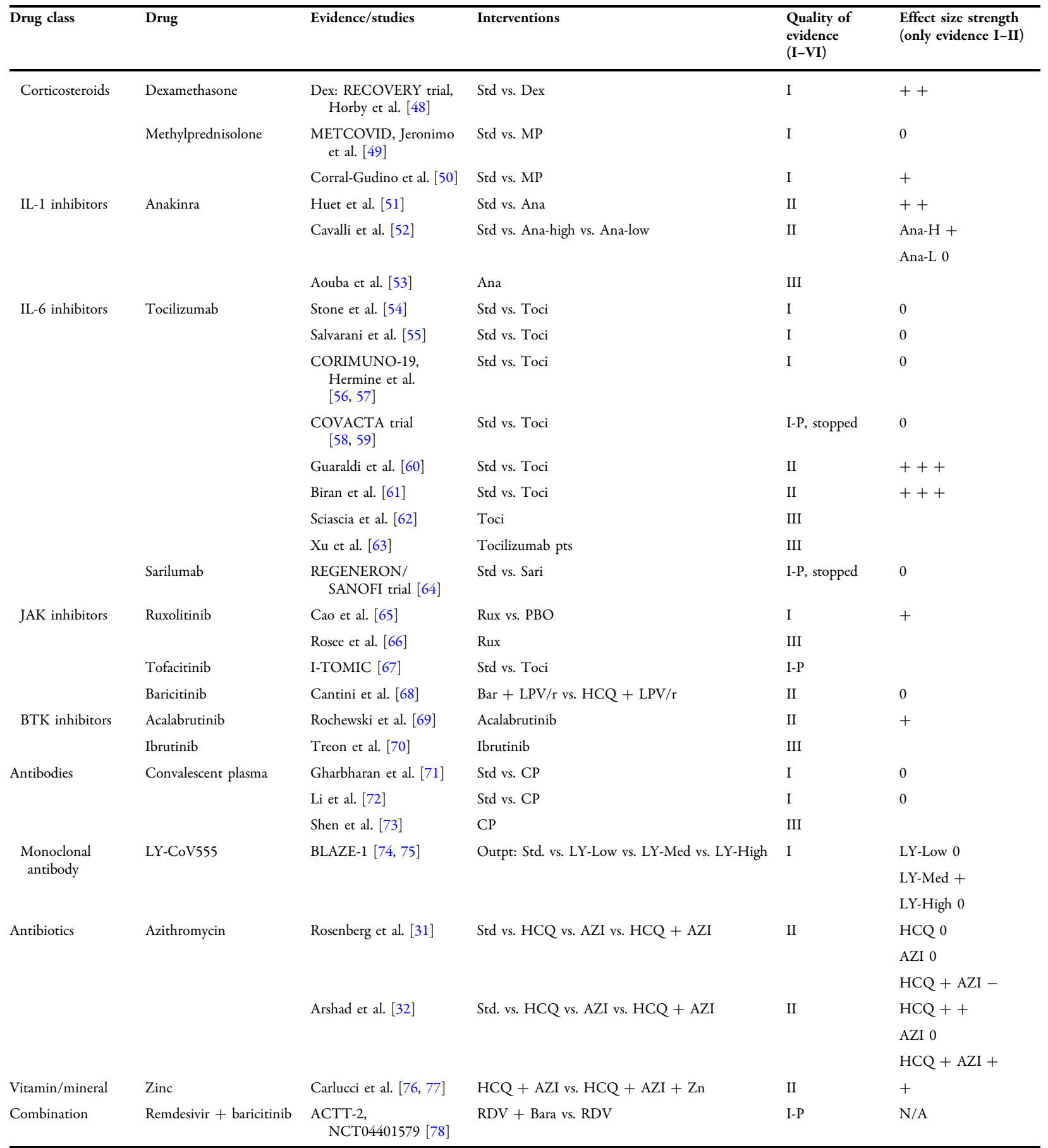

$R D V$ remdesivir, $P B O$ placebo, $S t d$ standard of care, $C L Q$ chloroquine, $H C Q$ hydroxychloroquine, $A Z I$ azithromycin, $F P V$ favipiravir, $L P V / r$ lopinavir/ritonavir, $S O F /$ $D C V$ sofosbuvir/daclatasvir, $R B V$ ribavirin, Dex dexamethasone, INF interferon- $\beta 1$ a, $p t$ patient, Ana anakinra, Sari sarilumab, Rux ruxolitinib, Toci tofacitinib, Bar baricitinib, $C P$ convalescent plasma, $5 d 5$ days of therapy, $10 d 10$ days of therapy, $N / A$ not applicable 
and is the current recommended dosage under the NIH guidelines.

- Remdesivir dosing table

\begin{tabular}{cc}
\hline Dosing & $200 \mathrm{mg}$ IV once $\times 1$ day, $100 \mathrm{mg}$ IV \\
& $\mathrm{QD} \times 4$ or 9 days \\
Duration & 5 days $(\leq 94 \% \mathrm{SpO}$, and not requiring \\
& mechanical ventilation and/or ECMO) \\
& Can extend to (if no clinical improvement \\
& demonstrated) 10 days (mechanical \\
& ventilation and/or ECMO) \\
Adverse & Adverse events were mostly mild-moderate: \\
effects & hepatic enzyme elevations, diarrhea, rash, \\
& etc. [21]
\end{tabular}

$I V$ intravenous, $Q D$ daily, ECMO extracorporeal membrane oxygenation

\section{Chloroquine/Hydroxychloroquine}

Chloroquine (CQ) and hydroxychloroquine (HCQ) are pharmacologic therapies exhibit in vitro antiviral activity against SARS-CoV-2 [24]. HCQ is a derivative of chloroquine with an extra hydroxyl group and has been shown to be less toxic than CQ in animal studies [85]. Initially, both agents had been used as antimalarial drugs as derivatives of quinine, then later became used as immunomodulatory drugs for autoimmune and rheumatic diseases upon approval in 1956. In addition to their immunoregulatory and anti-inflammatory properties, their proposed antiviral effects are thought to be mediated by changes in the cell membrane $\mathrm{pH}$ necessary for viral fusion and interference of glycosylation of viral proteins [86]. The chloroquine analogues seemed to emerge in clinical trials as potential treatment options against the novel coronavirus [87]. Initially, chloroquine had been studied in 23 clinical trials in China, in addition to promising in vitro research. Hydroxychloroquine, alone and in combination, had even more results available in late spring 2020. This initial treatment use for hydroxychloroquine and chloroquine was driven by a lower quality of evidence until RCTs confirmed the lack of efficacy of the treatment $[15,24-27,37]$.

One such early study, a non-randomized trial, emerged in mid-March from a group of researchers in Marseille, France, which described the preliminary use of HCQ $(200 \mathrm{mg}$ TID) \pm azithromycin (AZI) (500 $\mathrm{mg}$ on day 1 followed by $250 \mathrm{mg}$ per day, the next 4 days) in 26 patients compared to a control group, which received supportive care only [37]. The addition of azithromycin in this trial is interesting for its noted anti-inflammatory properties, but additional data suggested potential antiviral mechanisms [88]. Viral clearance in nasopharyngeal swabs was achieved in 6/6 (100\%) patients in the HCQ + AZI group and 8/14 (57\%) in the HCQ monotherapy group [37]. This study drove much of the fervent interest in HCQ and AZI as a potential combination therapy for COVID-19. However, while preprint popularity drove initial use, full results have been published along with other results from similar studies. In the full results of the Gautret study, 80 patients were included with no control group, and the results can only be interpreted by inference to other studies on COVID-19 patients with standard supportive care. The final polymerase chain reaction (PCR) results in the complete study were less impressive with roughly $40 \%$ of 80 patients having a PCR-positive sample at day 5 compared with $0 \%$ in the interim results of HCQ + AZI above [37, 38].

The full Gautret study did not have a control group, so interpreting treatment efficacy is a challenge and represents a significant limitation of the study. However, since the publishing of the initial study results in Marseille, a group in Paris, France failed to replicate the positive preliminary results of Gautret and colleagues in a prospective study designed to assess both virologic and clinical outcomes in patients with severe COVID-19. The study included 11 patients who received hydroxychloroquine (600 mg/day for 10 days) and azithromycin (500 $\mathrm{mg}$ day 1 and $250 \mathrm{mg}$ days 2-5) using the same dosing regimen reported by Gautret et al. Repeated nasopharyngeal swabs at days 5-6 after treatment initiation were still positive in 
$8 / 10$ patients $(80 \%, 95 \%$ CI $49-94)$. The virologic results contrast those reported by Gautret, et al., which left unanswered questions regarding the role of this combination therapy in the treatment of COVID-19 [39]. After this series of studies, prospective randomized trials began to result, beginning in late March. The first of these came from Wuhan with somewhat positive results. In this study, 31 patients were randomized to 5 days of hydroxychloroquine (400 mg/day) and 31 patients were randomized to placebo. In the treatment group, chest CTs significantly improved in 25/31 (80.6\%) patients from day 0 to 6 , compared with the control group of $17 / 31(54.8 \%)$ [28]. While promising, the trial was underpowered to detect a significant outcome, and it was intended to recruit 300 patients at the outset, instead of the published 62 patients. In early May with the Tang study, RCTs began to illuminate the treatment's lack of efficacy more clearly and adverse events came to be more clearly documented. This trial had 75 participants in each group, HCQ and standard of care, across 16 hospital sites in China in February. Results focused on negative conversion of SARS-CoV-2 by 28 days, which was non-significantly different between the two groups, because only two patients with severe COVID-19 were enrolled for clinical outcome analysis. Frequency of adverse events was $9 \%$ in the standard of care group and 30\% in the HCQ group [27]. The lack of efficacy and higher adverse event results continued in three further large RCTs for hydroxychloroquine $[15,25,26]$.

At the time of this review, there are now at least five significant RCTs evaluating the use of hydroxychloroquine and azithromycin $[15,25-28]$. The RCTs have shown a lack of efficacy of hydroxychloroquine or azithromycin, in comparison to results from some non-randomized clinical retrospective trials $[32,33,36]$. Indeed, the addition of azithromycin may cause more harm than intended given the noted QT prolongation that can occur [89]. Hydroxychloroquine, chloroquine, and azithromycin have now fully fallen out of favor because of the overall study results. The SOLIDARITY trial in combination with other RCTs like ACTT-1 has now settled the question of any therapeutic efficacy for hydroxychloroquine. For historical dosing reference when they were utilized, refer to the hydroxychloroquine dosing table for a brief review on regimens.

\section{- Hydroxychloroquine dosing table}

Note: Most dosing regimens have been extrapolated from pharmacokinetics (PK) parameters described in patients with rheumatic diseases or healthy volunteers; therefore, PK studies are still needed to determine the optimal dosing regimen in patients with COVID-19 [90].

\begin{tabular}{|c|c|}
\hline Dosing strategies & Reference/indication \\
\hline $\begin{array}{l}800 \mathrm{mg} \text { followed by } \\
400 \mathrm{mg} \text { at } 6,24,48,72 \text {, } \\
\text { and } 96 \mathrm{~h}\end{array}$ & $\begin{array}{l}\text { FDA approved adult dosing } \\
\text { for treatment of acute } \\
\text { malaria extended to } 5 \text { days. }\end{array}$ \\
\hline $\begin{array}{l}3 \text { days (acute malaria } \\
\text { treatment) }\end{array}$ & $\begin{array}{l}\text { Recommended most } \\
\text { reasonable, efficacious, and }\end{array}$ \\
\hline $5-10$ days & $\begin{array}{l}\text { safest approach by Downes' } \\
\text { dosing simulations [91] }\end{array}$ \\
\hline $\begin{array}{l}400 \mathrm{mg} \text { BID } \times 2 \text { doses, } \\
\text { then } 200 \mathrm{mg} \text { PO BID } \\
5 \text { days }\end{array}$ & $\begin{array}{l}\text { Optimal regimen } \\
\text { recommended by Yao } \\
\text { et al. [92] }\end{array}$ \\
\hline Prefer to give with food & \\
\hline $200 \mathrm{mg}$ TID $\times 10$ days & $\begin{array}{l}\text { Dosing from Gautret et al. } \\
\text { [37] }\end{array}$ \\
\hline $400 \mathrm{mg}$ QD $\times 10$ days & $\begin{array}{l}\text { Maximal approved adult } \\
\text { dosing for rheumatologic } \\
\text { conditions }\end{array}$ \\
\hline $\begin{array}{l}800 \mathrm{mg} \text { on day } 1 \text {, then } \\
200 \mathrm{mg} \text { BID for } 7 \text { days }\end{array}$ & $\begin{array}{l}\text { For ICU patients with } \\
\text { COVID-19, } \\
\text { recommended from } \\
\text { prospective study } \\
\text { describing PK of HCQ in } \\
13 \text { patients }[90]\end{array}$ \\
\hline
\end{tabular}

Adverse effects: Usually mild severity-GI intolerances, cytopenias, QT prolongation, headaches, dizziness 
Table b continued

\begin{tabular}{l}
\hline Dosing strategies \\
\hline Warning: A recent cohort study found that the addition \\
of azithromycin to hydroxychloroquine was associated \\
with greater changes in QTc as compared to \\
hydroxychloroquine alone. Close monitoring of QTc \\
should be utilized with concomitant medication usage \\
[89]
\end{tabular}

FDA Food and Drug Administration, $P O$ by mouth, BID twice a day, $G I$ gastrointestinal, $T I D$ three times a day, $Q D$ daily, $I C U$ intensive care unit

\section{Lopinavir/Ritonavir}

Lopinavir/ritonavir (LPV/r) is a combination drug that is FDA approved for the treatment of HIV infection. It combines a protease inhibitor and a pharmacokinetic enhancer, where the enhancer is used to increase the effectiveness and concentration of lopinavir. Lopinavir/ritonavir has been identified as a potential treatment option against SARS-CoV-2 given its documented in vitro antiviral activity against SARS-CoV-1 [93]. The proposed mechanism of action suggests lopinavir inhibits the main protease of SARS-CoV-1, which stops viral replication [94]. One of the first RCTs evaluating lopinavir/ritonavir's efficacy was conducted in patients with severe COVID-19 in January to February in China, with results published midMarch. This study helped to temper any enthusiasm for lopinavir/ritonavir as a potential treatment early in the US COVID-19 treatment experience. The study included 199 patients and compared the clinical outcomes between patients who received LPV/r and supportive care only. The study found no significant difference mortality at 28 days or viral clearance, nor did it identify an association between the addition of $\mathrm{LPV} / \mathrm{r}$ and clinical improvement, defined as improvement of two points on a seven-category ordinal scale or discharge from the hospital. However while primary results showed little efficacy, post hoc analyses found statistical significance in median time to clinical improvement for the LPV/r group (1 day shorter, HR 1.39 , 95\% CI 1.00-1.91) when removing patients that experienced death before getting the drug and for patients receiving therapy within 12 days of onset of symptoms [44]. This minor positive signal in the data would continue questions of efficacy around lopinavir/ritonavir until further studies confirmed the lack of a benefit. One study conducted in China evaluated LPV/r in mild-moderate COVID-19 and compared this against usual care with a comparator arm of umifenovir (Arbidol), a broad antiviral medication used against influenza. The study was limited by its low sample size of 86 patients, but found no benefit of $\mathrm{LPV} / \mathrm{r}$ in the rate of positive-to-negative conversion of SARS-CoV-2 nucleic acid or improvement in symptoms or imaging. In fact, the therapy only increased adverse events from primarily diarrhea and loss of appetite in the LPV/r arm [42].

While a somewhat positive signal for treatment deep in the data from the Cao et al. study may have been present, any question of therapeutic benefit has since been ended with the RECOVERY trial results from over 4500 patients. With 1596 patients randomized to LPV/r and 3376 randomized to standard of care, it was found that there was no significant difference in mortality, progression to mechanical ventilation, or length of hospital stay in either group [43]. In addition to the RECOVERY trial results, results were further solidified with the subsequent SOLIDARITY trial data which showed a lack of any mortality benefit to lopinavir/ritonavir. The SOLIDARITY trial involved 1411 patients randomized to lopinavir, 651 to interferon plus lopinavir, and 4088 no study drug at 405 hospitals in 30 countries. Lopinavir showed no statistically significant effect on mortality (RR1.00, CI 0.79-1.25, $p=0.97$ ) [15]. Given the volume of patients involved in these two major trials, this has since shuttered further research into this drug being of benefit to patients with COVID-19. The dosing for lopinavir/ritonavir is 
documented below for completeness and historical sake, but it is no longer considered a viable treatment option for COVID-19.

- Lopinavir/ritonavir dosing table

\begin{tabular}{ll}
$\begin{array}{l}\text { Dosing } \\
\text { Duration }\end{array}$ & $\begin{array}{c}\text { PO: } 400 / 100 \mathrm{mg} \text { (2 tabs) BID } \\
\text { 5-10 days. Up to } 14 \text { total days of therapy } \\
\text { have been reported, but most patients have } \\
\text { adverse effects requiring early termination } \\
\text { of drug combination }\end{array}$ \\
$\begin{array}{c}\text { Adverse } \\
\text { effects }\end{array}$ & $\begin{array}{c}\text { moderate/severe-GI intolerance, } \\
\text { hepatitis, and LFT abnormalities }\end{array}$ \\
\hline
\end{tabular}

$P O$ by mouth, $B I D$ twice a day, $G I$ gastrointestinal, $L F T$ liver function

\section{Other Antiviral Drugs}

Other antiviral drugs have been studied for the treatment of COVID-19, and these include favipiravir, umifenovir (Arbidol), galidesivir, drugs currently utilized against influenza (oseltamivir, etc.), and sofosbuvir/daclatasvir. These antiviral drugs have not shown significant data to support their use. Some, like oseltamivir, have been ruled out as agents to use for COVID19 given the lack of positive in vitro data and absence of plausible mechanism of action [46]. Favipiravir and umifenovir are broad antivirals approved in countries outside the USA that were used as anti-influenza agents. Both drugs have had limited clinical data supporting their use, although there has been some in vitro data $[40,42,95,96]$. Sofosbuvir/daclatasvir is a treatment for hepatitis $\mathrm{C}$ infection that has also been found to bind to SARS-CoV-2 [97]. In a limited non-randomized study, it was found to have positive outcomes in COVID-19. However the trial was of limited participants and the comparison group was against ribavirin, which had significantly more adverse events as a therapy and it is not one commonly used in COVID-19 [45].

\section{Immunomodulating Drugs}

Literature from prior acute viral respiratory illnesses suggests that patients can progress to ARDS quite rapidly, as a result of the patient's own immune system becoming activated in a mechanism similar to sepsis. In addition, emerging evidence suggests that a subgroup of patients with severe COVID-19 might have a cytokine release syndrome (CRS), which is characterized by a substantial release of proinflammatory cytokines including interleukins (IL)-6, IL-1, tumor necrosis factor- $\alpha$ (TNF $\alpha$ ), and others [98]. This hyperinflammatory state when induced from COVID-19 can often lead to poor outcomes and ICU admission [99]. This section of drug therapy discusses immunomodulating drugs which aim to affect the immune response to SARS-CoV-2 and hope to limit hyperinflammatory responses which can further exacerbate a patient's illness.

\section{Corticosteroids}

Corticosteroids are a broadly acting immunosuppressant at high doses that work to limit the hyperactive response in the immune system. These drugs were initially thought to be a poor choice due to data from SARS and MERS outbreaks that showed variable outcomes and higher mortality [8]. However, large RCT data from the RECOVERY trial has shown mortality benefit with dexamethasone. Among 2104 patients allocated to dexamethasone $6 \mathrm{mg}$ given once daily for up to 10 days compared with 4321 patients allocated to usual care, a significant decrease in 28-day mortality was noted in the treatment arm $(21.6 \%$ vs. $24.6 \%$, RR 0.83 , CI 0.74-0.92) [48]. These results extend chiefly to those patients who were receiving invasive mechanical ventilation and those patients receiving oxygen support. Given differences in steroids used, questions remain whether this mortality benefit extends to other corticosteroids besides dexamethasone. The GLUCOCOVID study was a study involving 34 patients randomized with 22 patients preferred by clinicians to receive methylprednisolone (MP) $40 \mathrm{mg}$ every $12 \mathrm{~h} \times 3$ days then $20 \mathrm{mg}$ every $12 \mathrm{~h} \times 3$ days. This was compared against 29 
patients in the control group. The composite endpoint was of death, admission to the ICU, and ventilation requirement, which was significant between groups in intention-to-treat analysis (RR 0.55, CI 0.33-0.91) [50]. However, the use of methylprednisolone was further complicated with results from the METCOVID RCT where 393 patients were ultimately analyzed between methylprednisolone at $0.5 \mathrm{mg} / \mathrm{kg}$ twice daily for 5 days versus placebo. METCOVID did not show a mortality difference at day 28 between the groups, and only showed a difference in the subgroup analysis in patients over 60 years old, who had a lower mortality rate. METCOVID also provided evidence on adverse events with worsening diabetes evident from patients in the MP group who required more insulin therapy [49]. These data, especially from the high-powered RECOVERY trial, suggest that corticosteroids (specifically dexamethasone) are one of the mainstays of treatment for COVID-19 to reduce mortality. The data from METCOVID and GLUCOCOVID provides some conflicting evidence whether other corticosteroids can be used, such as methylprednisolone, yet this question explains why healthcare practice and guidelines specify dexamethasone over other alternative corticosteroids.

\section{IL Inhibitors}

One of the sets of proinflammatory cytokines, interleukins (IL), have been identified as a risk factor for worsened illness in COVID-19 and as a possible target for inhibition. Primary biomarkers and targets of interest lie with IL-1 and IL-6 [99]. In analysis of patients with severe COVID-19 illness, it was found that patients with more severe illness had higher IL-6 levels and this biomarker seemed to correlate with worse outcomes [4]. As a result, investigation began into the use of IL inhibitors, specifically tocilizumab and subsequently sarilumab for IL6 and anakinra for IL-1, to identify their role in patients with severe COVID-19.

One of the first studies to document the use of IL inhibitors was with tocilizumab. Reported from China, a single-arm study included 21 patients who received one dose of tocilizumab $400 \mathrm{mg}$ IV in addition to standard of care.
Although the follow-up period was relatively short at 2 weeks, $75 \%$ of patients experienced improved respiratory function after treatment [63]. This initial trial led many institutions internationally to use IL inhibitors because there were few data to support any COVID-19 treatments at the time. Many centers began using these agents and studying retrospectively whether these agents did indeed lower mortality and lead to better outcomes. Retrospective studies involving tocilizumab used in a nonrandomized method with statistical analysis adjusting for propensity scores and illness severity showed favorable outcomes regarding mortality $[60,61]$. However, when IL-6 inhibitors were studied in an RCT environment, these results were not replicated. The COVACTA trial was a global, randomized, double-blind, placebo-controlled phase III trial studying whether tocilizumab leads to improved clinical status in COVID-19. An interim report on July 29, 2020, by the trial sponsors showed that there was no difference regarding improved clinical status on a seven-point scale between tocilizumab and placebo (OR [odds ratio] 1.19, 95\% CI 0.81, 1.76), no difference in percentage of patients who died by week 4 in either group (difference $0.3 \%, 95 \%$ CI $-7.6 \%, 8.2 \% ; p=0.9410)$, and no difference in ventilator-free days $[58,59]$. The full results would be submitted for publication in a peer-reviewed journal, but the study was halted at that report after its primary endpoint showed no difference. Simultaneously with this tocilizumab trial that occurred, a phase II-III trial of sarilumab at $400 \mathrm{mg}$ was begun along with minor recruitment of a second cohort of sarilumab at $800 \mathrm{mg}$ compared against placebo. The primary analysis group included 194 patients who were critically ill with COVID-19 and were receiving mechanical ventilation at time of enrollment. This trial with sarilumab was also subsequently halted because it did to not meet its primary endpoint of improvement on a seven-point scale. Detailed results are also pending submission [64]. While initial use of IL inhibitors seemed positive according to early reports and retrospective analyses, RCTs have thus far failed to find any significant outcomes from this treatment. Three subsequent RCTs that have 
finalized results for tocilizumab (using $8 \mathrm{mg} / \mathrm{kg}$ IV) versus placebo have all failed to find any significant mortality difference with tocilizumab use or any statistical improvement on the WHO clinical progression scale (measuring symptoms/disease progression) [54-57]. While initial hopes for this treatment were high, subsequent RCT data has tempered hopes for this pharmacologic treatment modality. With limited evidence to support the use of tocilizumab, the treatment should now only be used in a restricted manner in the context of further clinical trials.

- Tocilizumab dosing table

\begin{tabular}{ll}
\hline Dosing & Initial dose of $400 \mathrm{mg}$ (flat dose) [63] or \\
& $4-8 \mathrm{mg} / \mathrm{kg}$ (rheum) infused over more \\
& than $60 \mathrm{~min}$ \\
& If initial dose not effective, may administer \\
& second dose (in same dosage as initial dose) \\
& after $12 \mathrm{~h}$ \\
& No more than 2 doses should be given; \\
& maximum single dose is $800 \mathrm{mg}$ \\
Adverse & Increased risk of infection, injection site \\
effects & reactions, elevated liver enzymes, risk of GI \\
& perforation
\end{tabular}

GI gastrointestinal

\section{Kinase Inhibitors}

Both Janus kinase (JAK) inhibitors and Bruton tyrosine kinase (BTK) inhibitors interfere with cytokine signaling by inhibiting their respective enzymes. By impairing the production of proinflammatory cytokines, their theorized mechanism of action in the treatment of COVID-19 is to reduce inflammation and frequency of immunopathologies [100].

JAK Inhibitors As described in the following studies, ruxolitinib has demonstrated positive results in recent clinical trials and serves as another potential agent to be considered for patients with COVID-19-associated cytokine storm. After recent completion of a phase II trial, in which 22 patients received ruxolitinib $5 \mathrm{mg}$ PO BID, the results demonstrated safety and efficacy in a small subset of patients with significant improvement on the follow-up chest CT scans at day 14 and a significant decrease in cytokine levels [65]. As a result, phase III clinical trial, named RUXCOVID (NCT04362137), has been initiated and is currently recruiting patients to further assess the safety and efficacy of ruxolitinib $5 \mathrm{mg}$ PO BID or placebo plus standard of care for a total of 14 days in patients with COVID-19-associated cytokine storm [101]. Higher doses, including up to $20 \mathrm{mg}$ BID, have been reported in small, non-randomized, prospective cohort studies without serious adverse effects [66, 102]. However, an Expanded Access Program is open for enrollment of eligible patients with COVID-19-associated cytokine storm, in which they will receive ruxolitinib $5 \mathrm{mg}$ PO twice daily [103]. The remaining JAK inhibitor under investigation for treatment of COVID-19 is tofacitinib, which is FDA approved for the treatment of rheumatoid arthritis [104]. Tofacitinib is currently under a phase II trial, given the name I-TOMIC (NCT04415151), which is recruiting patients for the treatment of moderate COVID-19 [105]. The intervention will be tofacitinib administered in a dose of $10 \mathrm{mg}$ PO BID until return to their clinical baseline (as defined by need for supplementary oxygen), and will continue to be administered at $5 \mathrm{mg}$ PO BID for a total duration of therapy of 14 days. Another JAK inhibitor to mention is baricitinib, which is currently being investigated in the phase III clinical trial ACTT-2 (NCT04401579), which will evaluate the combination of remdesivir and baricitinib compared to remdesivir alone [78]. So far, only the results from a small non-randomized study examining the safety and clinical impact of baricitinib therapy plus lopinavir/ritonavir compared to standard of care (combination lopinavir/ritonavir and hydroxychloroquine) has shown a significant decrease in C-reactive protein (CRP) levels and shorter time to improvement of COVID-19 symptoms [68]. However, this study was unable to demonstrate any efficacy 
standard because of the lack of a proper control group.

BTK Inhibitors Acalabrutinib is currently being investigated in an active phase II trial, called CALAVI US (NCT04380688), which aims to assess the safety, efficacy, and pharmacokinetics of acalabrutinib in patients with COVID19 [106]. Similarly, phase II randomized trial, named iNSPIRE (NCT04375397), is currently recruiting patients to assess safety as well as the impact of ibrutinib on the incidence of respiratory failure in patients with COVID-19 [107]. Until now, the data to support the use of BTK inhibitors for COVID-19 treatment has stemmed from various retrospective trials with small sample sizes, which also lack control groups $[69,70]$. Unless data becomes available from the aforementioned phase II trials, the NIH recommends, at this time, against the use of BTK and JAK inhibitors for the treatment of COVID-19, except in a clinical trial [14].

\section{OTHER THEORETICAL/POTENTIAL TREATMENTS}

There are a growing number of potential therapies that show in vitro activity, potential in vitro activity, biologically plausible mechanisms of inhibition, and theoretical benefit in patients who are infected or may become infected. The treatments mentioned in Table 4 are by no means a comprehensive list, but it is a list to identify other potential medications that have had increased scrutiny during this pandemic but are somewhat less well known or discussed. All other therapies not mentioned in the above sections show even less evidence of efficacy and safety. Some treatments such as convalescent plasma have been investigated with little evidence of benefit in randomized clinical trials [71, 72]. However, the FDA has released an EUA for convalescent plasma, citing these RCTs among other non-randomized data, concluding that the "potential benefits of the product outweigh the known" risks [108]. The current NIH guidelines do not support the use of convalescent plasma outside of a clinical trial, and the evidence for its broad use in patients to treat COVID-19 is lacking. This treatment, among others, should be assessed with the utmost care regarding risks over benefits, with preference to avoid any therapy in non-clinical trial scenarios until further evidence supporting use is elucidated.

The road to effective COVID-19 pharmacologic options has been a difficult one, and one in which we still do not have robust exciting answers. Dexamethasone remains the drug for treatment of severe COVID-19 that may decrease mortality, and remdesivir has proven to have less of a positive clinical benefit than once thought. Many of the treatments above were used liberally in the early stages of the pandemic with little supportive evidence, and this review should provide context on how evidence can change and evolve when correctly focusing on high-level RCTs to determine treatment efficacy and safety.

\section{ACKNOWLEDGEMENTS}

Funding. No funding or sponsorship was received for this study or publication of this article.

Authorship. All named authors meet the International Committee of Medical Journal Editors (ICMJE) criteria for authorship for this article, take responsibility for the integrity of the work as a whole, and have given their approval for this version to be published.

Disclosures. Nicholas Rebold, Dana Holger, Sara Alosaimy, Taylor Morrisette and Michael Rybak have nothing to disclose.

Compliance with Ethics Guidelines. This article is based on previously conducted studies and does not contain any new studies with human participants or animals performed by any of the authors.

Open Access. This article is licensed under a Creative Commons Attribution- 
NonCommercial 4.0 International License, which permits any non-commercial use, sharing, adaptation, distribution and reproduction in any medium or format, as long as you give appropriate credit to the original author(s) and the source, provide a link to the Creative Commons licence, and indicate if changes were made. The images or other third party material in this article are included in the article's Creative Commons licence, unless indicated otherwise in a credit line to the material. If material is not included in the article's Creative Commons licence and your intended use is not permitted by statutory regulation or exceeds the permitted use, you will need to obtain permission directly from the copyright holder. To view a copy of this licence, visit http://creative commons.org/licenses/by-nc/4.0/.

\section{REFERENCES}

1. Epidemic and peace, 1918. Med Hist. 1978;22:111.

2. WHO. Coronavirus disease (COVID-19). World Health Organization. https://www.who.int/ emergencies/diseases/novel-coronavirus-2019. Accessed 14 July 2020.

3. CDC. Coronavirus disease 2019 (COVID-19). Centers for Disease Control and Prevention. 2020. https:// www.cdc.gov/coronavirus/2019-ncov/infectioncontrol/control-recommendations.html. Accessed 13 Mar 2020.

4. Wang $\mathrm{D}, \mathrm{Hu} \mathrm{B}, \mathrm{Hu} \mathrm{C}$, et al. Clinical characteristics of 138 hospitalized patients with 2019 novel coronavirus-infected pneumonia in Wuhan, China JAMA. 2020;323:1061-9. https://doi.org/10.1001/ jama.2020.1585.

5. WHO. Prospective study of the clinical progression and viral load of SARS associated coronavirus pneumonia in a community outbreak. WHO. https://www.who.int/csr/sars/prospectivestudy/en/. Accessed 18 Oct 2020.

6. Bhimraj A, Morgan RL, Shumaker AH, et al. Infectious Diseases Society of America Guidelines on the treatment and management of patients with COVID-19. Clin Infect Dis. 2020;15:14. https://doi. org/10.1093/cid/ciaa478.

7. Garfield S. The rise and fall of AZT: it was the drug that had to work. The Independent. 2011. https:// www.independent.co.uk/arts-entertainment/therise-and-fall-of-azt-it-was-the-drug-that-had-to-workit-brought-hope-to-people-with-hiv-and-2320491. html Accessed 14 July 2020.

8. Auyeung TW, Lee JSW, Lai WK, et al. The use of corticosteroid as treatment in SARS was associated with adverse outcomes: a retrospective cohort study. J Infect. 2005;51:98-102. https://doi.org/10. 1016/j.jinf.2004.09.008.

9. Sheahan TP, Sims AC, Leist SR, et al. Comparative therapeutic efficacy of remdesivir and combination lopinavir, ritonavir, and interferon beta against MERS-CoV. Nat Commun. 2020. https://doi.org/10. 1038/s41467-019-13940-6.

10. Tan ELC, Ooi EE, Lin C-Y, et al. Inhibition of SARS coronavirus infection in vitro with clinically approved antiviral drugs. Emerg Infect Dis. 2004;10: 581-6. https://doi.org/10.3201/eid1004.030458.

11. Chu CM, Cheng VCC, Hung IFN, et al. Role of lopinavir/ritonavir in the treatment of SARS: initial virological and clinical findings. Thorax. 2004;59: 252-6. https://doi.org/10.1136/thorax.2003. 012658 .

12. Gu L, Schneller SW, Li Q. Assays for the identification of novel antivirals against bluetongue virus. J Vis Exp. 2013. https://doi.org/10.3791/50820.

13. Morrisette T, Lodise TP, Scheetz MH, Goswami S, Pogue JM, Rybak MJ. The pharmacokinetic and pharmacodynamic properties of hydroxychloroquine and dose selection for COVID-19: putting the cart before the horse. Infect Dis Ther. 2020;9:561-72. https://doi.org/10.1007/s40121-020-00325-2.

14. NIH. Coronavirus disease 2019 (COVID-19) treatment guidelines. https://www.covid19treatment guidelines.nih.gov/. Accessed 13 Aug 2020.

15. Consortium WS trial, Pan H, Peto R, et al. Repurposed antiviral drugs for COVID-19-interim WHO SOLIDARITY trial results. medRxiv. Published online October 15, 2020:2020. https://doi.org/10. 1101/2020.10.15.20209817.

16. Beigel JH, Tomashek KM, Dodd LE, et al. Remdesivir for the treatment of covid-19-preliminary report. N Engl J Med. 2020. https://doi.org/10.1056/ NEJMoa2007764.

17. Beigel JH, Tomashek KM, Dodd LE, et al. Remdesivir for the treatment of covid-19-final report. N Engl J Med. 2020;383:1813-26. https://doi.org/10.1056/ NEJMoa2007764.

18. Wang Y, Zhang D, Du G, et al. Remdesivir in adults with severe COVID-19: a randomised, double-blind, placebo-controlled, multicentre trial. Lancet. 
2020;395:1569-78. https://doi.org/10.1016/S01406736(20)31022-9.

19. Goldman JD, Lye DCB, Hui DS, et al. Remdesivir for 5 or 10 days in patients with severe Covid-19. $\mathrm{N}$ Engl J Med. 2020. https://doi.org/10.1056/ NEJMoa2015301.

20. Spinner CD, Gottlieb RL, Criner GJ, et al. Effect of remdesivir vs standard care on clinical status at 11 days in patients with moderate COVID-19: a randomized clinical trial. JAMA. 2020;324:1048-57. https://doi.org/10.1001/jama.2020.16349.

21. Grein J, Ohmagari N, Shin D, et al. Compassionate use of remdesivir for patients with severe Covid-19. $\mathrm{N}$ Engl J Med. 2020. https://doi.org/10.1056/ NEJMoa2007016.

22. Holshue ML, DeBolt C, Lindquist S, et al. First case of 2019 novel coronavirus in the United States. N Engl J Med. 2020;382:929-36. https://doi.org/10. 1056/NEJMoa2001191.

23. Williamson BN, Feldmann F, Schwarz B, et al. Clinical benefit of remdesivir in rhesus macaques infected with SARS-CoV-2. Nature. 2020. https:// doi.org/10.1038/s41586-020-2423-5.

24. Wang M, Cao R, Zhang L, et al. Remdesivir and chloroquine effectively inhibit the recently emerged novel coronavirus (2019-nCoV) in vitro. Cell Res. 2020;30:269-71. https://doi.org/10.1038/ s41422-020-0282-0.

25. Cavalcanti AB, Zampieri FG, Rosa RG, et al. Hydroxychloroquine with or without azithromycin in mild-to-moderate Covid-19. N Engl J Med. 2020. https://doi.org/10.1056/NEJMoa2019014.

26. Horby P, Mafham M, Linsell L, et al. Effect of hydroxychloroquine in hospitalized patients with COVID-19: preliminary results from a multi-centre, randomized, controlled trial. Infect Dis (except HIV/AIDS). 2020;15:14. https://doi.org/10.1101/ 2020.07.15.20151852.

27. Tang W, Cao Z, Han M, et al. Hydroxychloroquine in patients with mainly mild to moderate coronavirus disease 2019: open label, randomised controlled trial. BMJ. 2019;2020:369. https://doi.org/ 10.1136/bmj.m1849.

28. Chen Z, Hu J, Zhang Z, et al. Efficacy of hydroxychloroquine in patients with COVID-19: results of a randomized clinical trial. Epidemiology. 2020. https://doi.org/10.1101/2020.03.22.20040758.

29. Magagnoli J, Narendran S, Pereira F, et al. Outcomes of hydroxychloroquine usage in United States veterans hospitalized with COVID-19. Med. 2020. https://doi.org/10.1016/j.medj.2020.06.001.
30. Mahévas M, Tran V-T, Roumier M, et al. Clinical efficacy of hydroxychloroquine in patients with covid-19 pneumonia who require oxygen: observational comparative study using routine care data. BMJ. 2020. https://doi.org/10.1136/bmj.m1844.

31. Rosenberg ES, Dufort EM, Udo T, et al. Association of treatment with hydroxychloroquine or azithromycin with in-hospital mortality in patients with COVID-19 in New York State. JAMA. 2020;323: 2493-502. https://doi.org/10.1001/jama.2020.8630.

32. Arshad S, Kilgore P, Chaudhry ZS, et al. Treatment with hydroxychloroquine, azithromycin, and combination in patients hospitalized with COVID-19. Int J Infect Dis. 2020;97:396-403. https://doi.org/ 10.1016/j.ijid.2020.06.099.

33. Yu B, Li C, Chen P, et al. Low dose of hydroxychloroquine reduces fatality of critically ill patients with COVID-19. Sci China Life Sci. 2020. https:// doi.org/10.1007/s11427-020-1732-2.

34. Ip A, Ahn J, Zhou Y, et al. Hydroxychloroquine in the treatment of outpatients with mildly symptomatic COVID-19: a multi-center observational study. Infect Dis (except HIV/AIDS). 2020. https:// doi.org/10.1101/2020.08.20.20178772.

35. Geleris J, Sun Y, Platt J, et al. Observational study of hydroxychloroquine in hospitalized patients with Covid-19. N Engl J Med. 2020;382:2411-8. https:// doi.org/10.1056/NEJMoa2012410.

36. Castelnuovo AD, Costanzo S, Antinori A, et al. Use of hydroxychloroquine in hospitalised COVID-19 patients is associated with reduced mortality: findings from the observational multicentre Italian CORIST study. Eur J Intern Med. 2020. https://doi. org/10.1016/j.ejim.2020.08.019.

37. Gautret P, Lagier J-C, Parola P, et al. Hydroxychloroquine and azithromycin as a treatment of COVID-19: results of an open-label non-randomized clinical trial. Int J Antimicrob Agents. 2020. https://doi.org/10.1016/j.ijantimicag.2020.105949.

38. Gautret P, Lagier J-C, Parola P, et al. Clinical and microbiological effect of a combination of hydroxychloroquine and azithromycin in 80 COVID-19 patients with at least a six-day follow up: a pilot observational study. Travel Med Infect Dis. 2020;34: 101663. https://doi.org/10.1016/j.tmaid.2020. 101663.

39. Molina JM, Delaugerre C, Le Goff J, et al. No evidence of rapid antiviral clearance or clinical benefit with the combination of hydroxychloroquine and azithromycin in patients with severe COVID-19 infection. Med Malad Infect. 2020;50:384. https:// doi.org/10.1016/j.medmal.2020.03.006. 
40. Cai Q, Yang M, Liu D, et al. Experimental treatment with favipiravir for COVID-19: an open-label control study. Engineering. 2020. https://doi.org/10. 1016/j.eng.2020.03.007.

41. ClinicalTrials.gov. A study to evaluate the safety, pharmacokinetics and antiviral effects of galidesivir in yellow fever or COVID-19 - no study results posted. https://clinicaltrials.gov/ct2/show/results/ NCT03891420. Accessed 21 Sep 2020.

42. Li Y, Xie Z, Lin W, et al. Efficacy and safety of lopinavir/ritonavir or arbidol in adult patients with mild/moderate COVID-19: an exploratory randomized controlled trial. Med. 2020. https://doi.org/10. 1016/j.medj.2020.04.001.

43. RECOVERY. Lopinavir-ritonavir results-RECOVERY Trial. https://www.recoverytrial.net/results/ lopinavar-results. Accessed 21 Sep 2020.

44. Cao B, Wang Y, Wen D, et al. A trial of lopinavirritonavir in adults hospitalized with severe Covid19. N Engl J Med. 2020. https://doi.org/10.1056/ NEJMoa2001282.

45. Eslami G, Mousaviasl S, Radmanesh E, et al. The impact of sofosbuvir/daclatasvir or ribavirin in patients with severe COVID-19. J Antimicrob Chemother. 2020. https://doi.org/10.1093/jac/dkaa331.

46. Tan Q, Duan L, Ma Y, et al. Is oseltamivir suitable for fighting against COVID-19: in silico assessment, in vitro and retrospective study. Bioorg Chem. 2020;104:104257. https://doi.org/10.1016/j. bioorg.2020.104257.

47. Deftereos SG, Giannopoulos G, Vrachatis DA, et al. Effect of colchicine vs standard care on cardiac and inflammatory biomarkers and clinical outcomes in patients hospitalized with coronavirus disease 2019: the GRECCO-19 Randomized Clinical Trial. JAMA Netw Open. 2020;3:e2013136. https://doi.org/10. 1001/jamanetworkopen.2020.13136.

48. Horby P, Lim WS, Emberson J, et al. Effect of dexamethasone in hospitalized patients with COVID19: preliminary report. MedRxiv. 2020. https://doi. org/10.1101/2020.06.22.20137273.

49. Jeronimo CMP, Farias MEL, Val FFA, et al. Methylprednisolone as adjunctive therapy for patients hospitalized with COVID-19 (Metcovid): a randomised, double-blind, phase IIb, Placebo-controlled trial. Clin Infect Dis. 2020. https://doi.org/ 10.1093/cid/ciaa1177.

50. Corral-Gudino L, Bahamonde A, delas Revillas AF, et al. GLUCOCOVID: A controlled trial of methylprednisolone in adults hospitalized with COVID-19 pneumonia. Infect Dis (except HIV/AIDS). 2020;15: 14. https://doi.org/10.1101/2020.06.17.20133579.
51. Huet $\mathrm{T}$, Beaussier $\mathrm{H}$, Voisin $\mathrm{O}$, et al. Anakinra for severe forms of COVID-19: a cohort study. Lancet Rheumatol. 2020;2:e393-400. https://doi.org/10. 1016/S2665-9913(20)30164-8.

52. Cavalli G, Luca GD, Campochiaro C, et al. Interleukin-1 blockade with high-dose anakinra in patients with COVID-19, acute respiratory distress syndrome, and hyperinflammation: a retrospective cohort study. Lancet Rheumat. 2020;2:e325-31. https://doi.org/10.1016/S2665-9913(20)30127-2.

53. Aouba A, Baldolli A, Geffray L, et al. Targeting the inflammatory cascade with anakinra in moderate to severe COVID-19 pneumonia: case series. Ann Rheum Dis. 2020. https://doi.org/10.1136/ annrheumdis-2020-217706.

54. Stone JH, Frigault MJ, Serling-Boyd NJ, et al. Efficacy of tocilizumab in patients hospitalized with Covid19. N Engl J Med. 2020. https://doi.org/10.1056/ NEJMoa2028836.

55. Salvarani C, Dolci G, Massari M, et al. Effect of tocilizumab vs standard care on clinical worsening in patients hospitalized with COVID-19 pneumonia: a randomized clinical trial. JAMA Intern Med. 2020. https://doi.org/10.1001/jamainternmed. 2020.6615 .

56. Assistance Publique-Hôpitaux de Paris. Press release. Tocilizumab improves significantly clinical outcomes of patients with moderate or severe COVID19 pneumonia. AP-HP; April 27, 2020. https:// pipelinereview.com. Accessed 27 July 2020.

57. Hermine O, Mariette X, Tharaux P-L, et al. Effect of tocilizumab vs usual care in adults hospitalized with COVID-19 and moderate or severe pneumonia: a randomized clinical trial. JAMA Intern Med. 2020. https://doi.org/10.1001/jamainternmed.2020.6820.

58. Furlow B. COVACTA trial raises questions about tocilizumab's benefit in COVID-19. Lancet Rheumatol. 2020. https://doi.org/10.1016/S26659913(20)30313-1.

59. Roche. Roche provides an update on the phase III COVACTA trial of Actemra/RoActemra in hospitalised patients with severe COVID-19 associated pneumonia. https://www.roche.com/investors/ updates/inv-update-2020-07-29.htm. Accessed 23 Sep 2020.

60. Guaraldi G, Meschiari M, Cozzi-Lepri A, et al. Tocilizumab in patients with severe COVID-19: a retrospective cohort study. Lancet Rheumatol. 2020;2:e474-84. https://doi.org/10.1016/S26659913(20)30173-9.

61. Biran N, Ip A, Ahn J, et al. Tocilizumab among patients with COVID-19 in the intensive care unit: a 
multicentre observational study. Lancet Rheumatol. 2020 . https://doi.org/10.1016/S2665-9913(20) 30277-0.

62. Sciascia S, Aprà F, Baffa $\mathrm{A}$, et al. Pilot prospective open, single-arm multicentre study on off-label use of tocilizumab in patients with severe COVID-19. Clin Exp Rheumatol. 2020;38:529-32.

63. Xu X, Han M, Li T, et al. Effective treatment of severe COVID-19 patients with tocilizumab. Proc Natl Acad Sci USA. 2020;117(20):10970-5. https:// doi.org/10.1073/pnas.2005615117.

64. Regeneron and Sanofi provide update on U.S. Phase $2 / 3$ adaptive-designed trial of KEVZARA ${ }^{\circledR}$ (sarilumab) in hospitalized COVID-19 patients [press release]. 2020. https://investor.regeneron.com/ news-releases/news-release-details/regeneron-andsanofi-provide-update-us-phase-23-adaptive/. Accessed 27 July 2020.

65. Cao Y, Wei J, Zou L, et al. Ruxolitinib in treatment of severe coronavirus disease 2019 (COVID-19): a multicenter, single-blind, randomized controlled trial. J Allergy Clin Immunol. 2020;146(137-146): e3. https://doi.org/10.1016/j.jaci.2020.05.019.

66. La Rosée F, Bremer HC, Gehrke I, et al. The Janus kinase $1 / 2$ inhibitor ruxolitinib in COVID-19 with severe systemic hyperinflammation. Leukemia. 2020. https://doi.org/10.1038/s41375-020-0891-0.

67. Yale University. Investigation of tofacitinib to mitigate the impact of COVID-19 (I-TOMIC) in moderate SARS-CoV-2 (MODERATE I-TOMIC). Clinical trials.gov; 2020. Identifier: NCT04415151. https:// clinicaltrials.gov/ct2/show/NCT04415151.

68. Cantini F, Niccoli L, Matarrese D, Nicastri E, Stobbione P, Goletti D. Baricitinib therapy in COVID-19: a pilot study on safety and clinical impact. J Infect. 2020;81:318-56. https://doi.org/10.1016/j.jinf. 2020.04.017.

69. Roschewski M, Lionakis MS, Sharman JP, et al. Inhibition of Bruton tyrosine kinase in patients with severe COVID-19. Sci Immunol. 2020. https:// doi.org/10.1126/sciimmunol.abd0110.

70. Treon SP, Castillo JJ, Skarbnik AP, et al. The BTK inhibitor ibrutinib may protect against pulmonary injury in COVID-19-infected patients. Blood. 2020;135:1912-5. https://doi.org/10.1182/blood. 2020006288.

71. Gharbharan A, Jordans CCE, Geurtsvankessel C, et al. Convalescent Plasma for COVID-19. A randomized clinical trial. medRxiv. Published online July 3, 2020. https://doi.org/10.1101/2020.07.01. 20139857.
72. Li L, Zhang W, Hu Y, et al. Effect of convalescent plasma therapy on time to clinical improvement in patients with severe and life-threatening COVID19. JAMA. 2020;324:1-11. https://doi.org/10.1001/ jama.2020.10044.

73. Shen C, Wang Z, Zhao F, et al. Treatment of 5 critically ill patients with COVID-19 with convalescent plasma. JAMA. 2020. https://doi.org/10.1001/jama. 2020.4783.

74. Eli Lilly and Company. Lilly announces proof of concept data for neutralizing antibody LY-CoV555 in the COVID-19 outpatient setting. https://investor. lilly.com/news-releases/news-release-details/lillyannounces-proof-concept-data-neutralizing-anti body-ly. Accessed 17 Sep 2020.

75. A study of LY3819253 (LY-CoV555) and LY3832479 (LY-CoV016) in participants with mild to moderate COVID-19 illness. Full text view. ClinicalTrials.gov. https:/clinicaltrials.gov/ct2/show/NCT04427501. Accessed 17 Sep 2020.

76. Carlucci P, Ahuja T, M Petrilli C, Rajagopalan H, Jones S, Rahimian J. Hydroxychloroquine and azithromycin plus zinc vs hydroxychloroquine and azithromycin alone: outcomes in hospitalized COVID-19 patients. 2020. https://doi.org/10.1101/ 2020.05.02.20080036.

77. Carlucci PM, Ahuja T, Petrilli C, Rajagopalan H, Jones S, Rahimian J. Zinc sulfate in combination with a zinc ionophore may improve outcomes in hospitalized COVID-19 patients. J Med Microbiol. 2020. https://doi.org/10.1099/jmm.0.001250.

78. National Institute of Allergy and Infectious Diseases (NIAID). A multicenter, adaptive, randomized blinded controlled trial of the safety and efficacy of investigational therapeutics for the treatment of COVID-19 in hospitalized adults (ACTT-2). Clinicaltrials.gov; 2020. Identifier: NCT04401579. https://www.clinicaltrials.gov/ct2/ show/NCT04401579.

79. Eastman RT, Roth JS, Brimacombe KR, et al. Remdesivir: a review of its discovery and development leading to emergency use authorization for treatment of COVID-19. ACS Cent Sci. 2020. https://doi.org/10.1021/acscentsci.0c00489.

80. U.S. Army Medical Research and Development Command. Intermediate-size patient population expanded access treatment protocol for coronavirus disease 2019 (COVID-19) remdesivir (RDV; GS$\left.5734^{\mathrm{TM}}\right)$. Clinicaltrials.gov; 2020. Identifier: NCT04302766. https://clinicaltrials.gov/ct2/show/ NCT04302766.

81. Gilead Sciences. Gilead Sciences statement on access to remdesivir outside of clinical trials. 
https://www.gilead.com/news-and-press/companystatements/gilead-sciences-statement-on-access-toremdesivir-outside-of-clinical-trials. Accessed 14 July 2020.

82. HCP Resources for Remdesivir (GS-5734 ${ }^{\mathrm{TM}}$ ) | Website for US HCPs. https://www.remdesivir.com/us/ resources/. Accessed 14 July 2020.

83. Search of: remdesivir | covid - Search Details - ClinicalTrials.gov. https://clinicaltrials.gov/ct2/results/ details?term=remdesivir\&cond=covid. Accessed 14 July 2020.

84. WHO. WHO recommends against the use of remdesivir in COVID-19 patients. https://www. who.int/news-room/feature-stories/detail/whorecommends-against-the-use-of-remdesivir-incovid-19-patients. Accessed 1 Dec 2020.

85. McChesney EW. Animal toxicity and pharmacokinetics of hydroxychloroquine sulfate. Am J Med. 1983;75:11-8. https://doi.org/10.1016/00029343(83)91265-2.

86. Alijotas-Reig J, Esteve-Valverde E, Belizna C, et al. Immunomodulatory therapy for the management of severe COVID-19. Beyond the anti-viral therapy: a comprehensive review. Autoimmun Rev. 2020;19: 102569. https://doi.org/10.1016/j.autrev.2020.102 569.

87. Al-Bari MAA. Targeting endosomal acidification by chloroquine analogs as a promising strategy for the treatment of emerging viral diseases. Pharmacol Res Perspect. 2017;5:e00293. https://doi.org/10.1002/ prp2.293.

88. Gielen V, Johnston SL, Edwards MR. Azithromycin induces anti-viral responses in bronchial epithelial cells. Eur Respir J. 2010;36:646-54. https://doi.org/ 10.1183/09031936.00095809.

89. Mercuro NJ, Yen CF, Shim DJ, et al. Risk of QT interval prolongation associated with use of hydroxychloroquine with or without concomitant azithromycin among hospitalized patients testing positive for coronavirus disease 2019 (COVID-19). JAMA Cardiol. 2019. https://doi.org/10.1001/ jamacardio.2020.1834.

90. Perinel S, Launay M, Botelho-Nevers É, et al. Towards optimization of hydroxychloroquine dosing in intensive care unit COVID-19 patients. Clin Infect Dis. 2020. https://doi.org/10.1093/cid/ ciaa394.

91. Downes K, Chiotos K, Fitzgerald J, Scheetz MH, Zuppa AF. Rational dosing of HCQ for COVID-19_ pre-print. Open Sci Framew. 2020. https://doi.org/ 10.31219/osf.io/py3kv.
92. Yao $\mathrm{X}$, Ye $\mathrm{F}$, Zhang $\mathrm{M}$, et al. In vitro antiviral activity and projection of optimized dosing design of hydroxychloroquine for the treatment of severe acute respiratory syndrome coronavirus 2 (SARSCoV-2). Clin Infect Dis. 2020. https://doi.org/10. 1093/cid/ciaa237.

93. Yao T-T, Qian J-D, Zhu W-Y, Wang Y, Wang G-Q. A systematic review of lopinavir therapy for SARS coronavirus and MERS coronavirus-a possible reference for coronavirus disease-19 treatment option. J Med Virol. 2020. https://doi.org/10.1002/jmv. 25729.

94. Ratia K, Pegan S, Takayama J, et al. A noncovalent class of papain-like protease/deubiquitinase inhibitors blocks SARS virus replication. Proc Natl Acad Sci. 2008;105:16119-24. https://doi.org/10.1073/ pnas.0805240105.

95. Boriskin YS, Leneva IA, Pécheur E-I, Polyak SJ. Arbidol: a broad-spectrum antiviral compound that blocks viral fusion. Curr Med Chem. 2008;15: 997-1005. https://doi.org/10.2174/ 092986708784049658.

96. Shannon A, Selisko B, Le N, et al. Favipiravir strikes the SARS-CoV-2 at its Achilles heel, the RNA polymerase. BioRxiv. 2020. https://doi.org/10.1101/ 2020.05.15.098731.

97. Elfiky AA. Ribavirin, remdesivir, sofosbuvir, galidesivir, and tenofovir against SARS-CoV-2 RNA dependent RNA polymerase (RdRp): a molecular docking study. Life Sci. 2020;253:117592. https:// doi.org/10.1016/j.lfs.2020.117592.

98. Li Y, Chen M, Cao H, Zhu Y, Zheng J, Zhou H. Extraordinary GU-rich single-strand RNA identified from SARS coronavirus contributes an excessive innate immune response. Microbes Infect. 2013;15: 88-95. https://doi.org/10.1016/j.micinf.2012.10. 008.

99. Mehta P, McAuley DF, Brown M, Sanchez E, Tattersall RS, Manson JJ. COVID-19: consider cytokine storm syndromes and immunosuppression. Lancet. 2020;395:1033-4. https://doi.org/10.1016/S01406736(20)30628-0.

100. Zhang W, Zhao Y, Zhang F, et al. The use of antiinflammatory drugs in the treatment of people with severe coronavirus disease 2019 (COVID-19): the perspectives of clinical immunologists from China. Clin Immunol. 2020;214:108393. https://doi.org/ 10.1016/j.clim.2020.108393.

101. ClinicalTrials.gov. Phase 3 randomized, doubleblind, placebo-controlled multi-center study to assess the efficacy and safety of ruxolitinib in patients with COVID-19 associated cytokine storm (RUXCOVID). Full text view. ClinicalTrials.gov. 
https://clinicaltrials.gov/ct2/show/NCT04362137. Accessed 18 Sep 2020.

102. Gozzetti A, Capochiani E, Bocchia M. The Janus kinase $1 / 2$ inhibitor ruxolitinib in COVID-19. Leukemia. 2020. https://doi.org/10.1038/s41375-02001038-8.

103. Incyte Corporation. An open-label expanded access program of ruxolitinib for the emergency treatment of cytokine storm from COVID-19 infection. Clinicaltrials.gov; 2020. Identifier: NCT04355793. https://clinicaltrials.gov/ct2/show/NCT04355793.

104. Tofacitinib (Xeljanz®) [package insert] . http://label ing.pfizer.com/ShowLabeling.aspx?id=959. Accessed 18 Sep 2020.

105. ClinicalTrials.gov. TOFacitinib in SARS-CoV2 pneumonia. Full text view. Clinicaltrials.gov. https://clinicaltrials.gov/ct2/show/NCT04332042. Accessed 12 Apr 2020.
106. ClinicalTrials.gov. Acalabrutinib study with best supportive care versus best supportive care in subjects hospitalized with COVID-19. Full text view. Clinicaltrials.gov. https://clinicaltrials.gov/ct2/ show/NCT04380688. Accessed 18 Sep 2020.

107. ClinicalTrials.gov. Study of oral ibrutinib capsules to assess respiratory failure in adult participants with severe acute respiratory syndrome coronavirus-2 (SARS-CoV-2) and pulmonary injury. Full text view. ClinicalTrials.gov. https://clinicaltrials. gov/ct2/show/NCT04375397. Accessed 18 Sep 2020.

108. FDA. FDA issues emergency use authorization for convalescent plasma as potential promising COVID-19 treatment, another achievement in Administration's fight against pandemic. FDA 2020. https://www.fda.gov/news-events/press-announce ments/fda-issues-emergency-use-authorizationconvalescent-plasma-potential-promising-covid-19treatment. Accessed 23 Sep 2020. 